\title{
O schematach ujmowania bliskiej i dalszej przeszłości. W kręgu metodologicznej refleksji historyczno-teoriopolitycznej
}

\section{Pytania nie tylko metodologicznej natury}

O gląd podejmowanych ostatnio publikacji, inicjatyw rocznicowych czy przedsięwzięć konferencyjnych, nawiązujących do przesłanek i swoistości zmiany politycznej zapoczątkowanej w 1989 r., skłania do podniesienia kwestii, która dotyczy zyskiwania na sile swoistej perspektywy interpretacyjnej przeszłości. Przedmiotem rozważań podejmowanych w różnych ośrodkach stają się nader często dwa okresy, między którymi - a nad czasami PRL-u - przerzuca się pomost. Tym samym sugeruje się istnienie między nimi pokrewieństwa ideowo-politycznego. Są nimi: 20-lecie międzywojenne oraz dwa dziesięciolecia mieszczące się między 1989 a 2011 rokiem. Jednocześnie - nie skrywając niechęci - pomniejsza się wartość dokonań w czasie poprzedzającym moment zmiany politycznej w $1989 \mathrm{r}$.

Godzi się tedy postawić pytanie, dlaczego w dziewięciu dziesięcioleciach, zwartego przecież czasowo okresu, obejmującego lata między 1919 a 2011 r., dokonuje się wyłomu, usuwając poza nawias analizy historycznej czas otwarty przywróceniem państwowości polskiej w 1944 r.? Czy zabieg ten jest logiczny i racjonalny? Czy u jego podstaw na pewno leżą względy merytoryczne? Czy dzieje się tak za sprawą klęski poniesionej przez Polską Rzeczypospolitą Ludową? Czy zasadne jest, traktowanie jej jak „,niegodny” epizod w dziejach narodu polskiego? Czy jej losy, które konceptualnie istotnie były próbą zerwania z przeszłością sanacyjną, „burżuazyjną”, będąc nieudanym, jak się wszakże okazało, eksperymentem socjalizmu biurokratycznego, winny być traktowane - posiłkując się nomenklaturą kosmiczną - jako „czarna dziura”. Pozostaje ona bowiem co najwyżej obszarem „oczywistych niegodziwości”, do tropienia których powołano dodatkowo specjalna, o ideologiczno-politycznym charakterze, instytucję (IPN). Jakie tedy przesłanki uzasadniają zastosowanie zabiegu wyłączenia - gospodarka (wolny rynek), wolności, swobody demokratyczne, czy wreszcie suwerenność, niepodległość?

Oto okres powojenny oraz ostatnie dwudziestolecie. W sferze wolnego rynku różnica jakościowa, ale czy droga doń - doktrynalny liberalizm, urzeczywistniany na wstępie środkami administracyjnymi, z podważeniem demokratycznych standardów - jest zdecydowanie odmienna od drogi realizacji idei „budownictwa socjalistycznego”? Wszak przejście z jednego ładu do drugiego odbywało się w zasadzie podobnie. Po 1944 r., osobliwie 1947-1948 - to doktrynalne rygory, wtedy wymuszane środkami administracyjnymi. Natomiast od momentu powstania rządu „,solidarnościowego" - to realizacja doktrynalnego, liberalnego konceptu,

\footnotetext{
* Artykuł stanowi znacznie poszerzoną wersją opracowania pt. Dwa dwudziestolecia...z PRL-em w tle, w: Dwa dwudziestolecia, red. P. Hauser, W. Mazurczak, Poznań 2010.
} 
dla urzeczywistnienia którego nie uzyskano świadomej zgody ze strony społeczeństwa ${ }^{1}$. Albowiem w kwestii wyboru sposobów odejścia od gospodarki realnosocjalistycznej i jego kosztów, poza blankietowym zaufaniem-przyzwoleniem okazanym w wyborach parlamentarnych - wszak plebiscytarnych - nowej ekipie rządowej przez społeczeństwo, zostało ono zaskoczone dokonywającymi się procesami ${ }^{2}$. Pod hasłami wolności i demokracji, odstapiono od ideałów „Solidarności” - bez redefinicji jej w przeważającej mierze socjalistycznego programu przyjętego przez I Zjazd (wrzesień-październik 1981 r.). Wybór nowej drogi - jakkolwiek konieczny - nie odbiegał od doktrynalnej dogmatyczności ${ }^{3}$, czego przejawem było lekceważenie rozwiązań alternatywnych, a w przypadku Polski 1989 r. niewrażliwość na ew. skutki społeczne ${ }^{4}$.

Czy z obszaru penetracji badawczej należy wykluczać takie właściwości 20-lecia międzywojennego jak wielkość obszarów nędzy, dostęp do dóbr materialnych i kulturalnych oraz wielkość grupy dotkniętej ubóstwem, strukturalną biedą, usytuowaną na marginesie postępu cywilizacyjnego ${ }^{5}$ ? Właściwości, z których część z natury związana była ze zmianą polityczną w 1989 r., a z którymi nie zdołano sobie poradzić, kiedy równocześnie podnosi się jej humanistyczne wartości. Dylematy pozostały.

Stawiając w ten sposób problem, zapewne dokonuje się nadmiernego wyostrzenia, jednakże uzasadnione jest to pytaniem: Dlaczego rozwiązania PRL-owskie apriorycznie uznaje się za niegodne uwagi badaczy? Czy wskutek niewątpliwej opresyjności i omnipotencji państwa? Czy ulegając owej perspektywie, należy pominąć, analizując procesy po 1989 r., pojawienie się osób niekorzystających z ,dobrodziejstw” zmiany społeczno-politycznej, rozpoczętej w 1989 r. pod hasłami wolności, demokracji, godności człowieczej, które zasilają grupe ,wykluczonych”, a odrzuconych przez liberalizm

Sferą, która wykazuje szereg odmienności między ostatnim dwudziestoleciem a okresem PRL, ma charakter polityczny. Wolności, pluralizm, podmiotowość polityczna, demokracja zmaterializowana przemiennością ekip politycznych etc. - to elementy, za pomocą których możliwe jest uchwycenie najistotniejszych różnic. O ile jednak podda się dokładniejszej analizie - stosując te kryteria - ową sferę, ponadto gdy za punkt wyjścia uczynić doktrynę autory-

${ }^{1}$ W 1989 r. wśród przedstawicieli nowego reżimu zdawano w 1989 r. sobie sprawę ze stanu nastrojów, wskazując na groźbę zmęczenia społecznego i utrzymujące się przekonanie, że, ,jacyś oni podejmują decyzje nie tylko za mnie, ale i przeciw mnie" - stwierdził B. Geremek na konferencji prasowej. Por. Konferencja prasowa przewodniczqcego OKP. Obok zagrożeń wiele nadziei, „Gazeta Wyborcza” z 10 października 1989.

${ }^{2}$ Szerzej K. B. Janowski, Źródła i przebieg zmiany politycznej w Polsce (1980-1989), Toruń 2004, s. 460.

${ }^{3} \mathrm{~Np}$. ówczesny wicepremier Leszek Balcerowicz pozostał jemu wierny, Natomiast jego ówczesny doradca i mentor - Jeffrey Sachs - zmodyfikował swoje podejście. Odmiennie niż Polak, kwestionuje ,pogląd o samoregulującym się rynku”, Sachs sądzi, że nie można uprawiać ekonomii ,jeśli nie dotknie się realnego życia, jeśli widzi się tylko ekonomię, a nie społeczeństwo, w którym ona działa, jeśli nie czuje się odpowiedzialności za losy ludzi, których życie zależy od gospodarki"; http://globaleconomy.pl/content/view/2949/10/;data dostępu 7 stycznia 2012.

4 „Polska szybko pojęła, że terapia szokowa dobrze się nadaje do zmniejszenia hiperinflacji, lecz jest zupełnie niewłaściwa do dokonania zmian społecznych”-powiada J. E. Stiglitz, laureat Nobla „ekonomicznego” 2001, krytykując dogmatyczne przekonanie o uniwersalności zalecanych przez MFW procedur ekonomicznych. Doświadczenia Polski (m.in.) „wskazują, że polityka stopniowych przemian prowadzi do mniejszych dolegliwości na krótką metę oraz do większej stabilności społecznej i politycznej, a także do szybszego wzrostu w dłuższym okresie. Okazuje się, że w wyścigu żółwia z zającem znowu wygrał żółw”. J. E. Stiglitz, Globalizacja, Warszawa 2007, s. 164 i 170.

${ }^{5}$ Analfabetów w wieku powyżej 10 lat było w 1921 r. 33,1\%, w 1931 r. 22,1\%. A. Czubiński, Historia Polski XX wieku, Poznań 2003, s. 179. Przed okupacją w 1939 r. odsetek analfabetów obniżył się do poziomu 15\% (W. Roszkowski, Historia Polski 1914-2004, Warszawa 2005, s. 86). Okres okupacji hitlerowskiej nie sprzyjał postępowi w eliminowaniu analfabetyzmu...

${ }^{6}$ D. Ost, Klęska ,Solidarności”. Gniew i polityka w postkomunistycznej Europie, Warszawa 2007. 
tarną, której reżim sanacyjny i powojenny, do 1989 r. były najbliższe, to okaże się, że występuje tu wiele podobieństw; terror, represywność, rozprawianie się z przeciwnikami politycznymi, mitologia ,początku”, kult przywódcy. Różnice tracą więc na zasadniczej wyrazistości, zachęcając do postrzegania owego całego okresu - przerwanego okupacją hitlerowską - jako swego rodzaju continuum, na którym lokuje się autorytaryzm i demokracja.

Osobliwie owe podobieństwa występują przy analizie działań grup (jednostek) pretendujących do miana elit politycznych, stylu uprawiania polityki, stosunku do przeciwników politycznych. Czy ich pozycja była ufundowana na demokratycznej woli społeczeństwa, czy autorytecie, wspieranym perswazją, siłą bądź manipulacją czy fałszem? Który z tych reżimów można uznać za bardziej ,uprawniony”? Czy międzywojenny, kiedy wolności i prawa obywatelskie początkowo tryumfując, doznały następnie uszczerbku poprzez zamach stanu (krwawy i przynoszący setki ofiar; jakie wnioski z porównania ze stanem wojennym?), praktykę rozprawiania się z opozycją i represywne ograniczanie jej działalności oraz system nepotyzmu wojskowego (kariery legionistów, rządy pułkowników), czy powojenny, który przez długi czas natrafiał na względne przyzwolenie, by nie powiedzieć aprobatę, pozostając wszakże poza standardami demokracji liberalnej?

Wreszcie sprawa suwerenności, niepodległości. Pytanie - na ile samodzielnym aktorem (bytem) na międzynarodowej scenie politycznej była Polska międzywojnia? Jakimi w ostatecznym rachunku dysponowała możliwościami zachowania niepodległego bytu? W jakich zaś ramach i warunkach geopolitycznych funkcjonowało państwo polskie po 1944 r.? Owe kwestie wypadnie rozważać w kontekście zasadności idei suwerenności absolutnej, wszak w praktyce nieznanej i niedoświadczanej. Albowiem suwerenność jest „,rozpostarta” między nieograniczonością, totalną niezależnością a pełnym podporządkowaniem. Między stanami krańcowymi sytuują się pośrednie. Kwestia zawiera się w zdolności państwa do realizacji swych interesów narodowych w konkretnych warunkach geopolitycznych, konkurencji, uzyskiwania przewagi, bądź zawierania sojuszy czy kompromisów, dokonywania wyborów, których sens sprowadza się do realnego pojmowania racji stanu ${ }^{7}$. Adwersarze Polski Ludowej - również z kręgu inteligencji - nie rozumieją tego, popadając w intelektualne lenistwo bądź nie potrafią oderwać się od prymitywnego, ideologicznego pojmowania dziejów.

Jawi się pytanie, w jakim stopniu ten swoisty sposób postrzegania przeszłości i jej odczytywania jest zbieżny z dominującymi w polityce polskiej ostatnich lat orientacjami ideowo-politycznymi. Nasuwa się bowiem generalna konkluzja. Nietrudno wszak zaobserwować wśród grup pretendujących do miana elit politycznych swoistą perspektywę postrzegania przeszłości, zapoczątkowaną przez zwycięską ekipę w 1989 r.:

1) gloryfikowanie 20-lecia międzywojennego. Tendencja pojawiła się oficjalnie w 1989 r., towarzysząc przeobrażeniom politycznym, ulegała wzmocnieniu bądź złagodzeniu. Eksponowana współcześnie przez główne partie prawicy (PO i PiS). Można mówić tu o przypadku schizofrenii. Wszak opozycja demokratyczna $\mathrm{w}$ ancien régime, do której nawiązują formacje polityczne legitymujące się rodowodem „Solidarności” walczyła o wolność, demokrację. Trudno doprawdy skonstatować ich tryumf za czasów sanacji. Jest to więc świadomy zabieg posługiwania się mitami, ale też manipulowania obrazem przeszłości;

2) zohydzanie okresu PRL, mieszanie prawdy z półprawdami i fałszem. Czyni się tak na potrzeby mało wyedukowanego odbiorcy. W gronie zaś inteligencji przeważa

\footnotetext{
${ }^{7}$ Por. K. Lastawski, Polska racja stanu po wstapieniu do Unii Europejskiej, Warszawa 2009.
} 
posługiwanie się stereotypami - totalitaryzm, komunizm, post-. Bezrefleksyjność, niewiedza, lenistwo poznawcze, kunktatorstwo - oto cechy tego podejścia;

3) przeciwstawianie PRL okresowi po 1989 r. Analogiczne - jak w przeszłości - przeważają tendencje zmierzające do przerwania ciągłości rozwojowej. Przełom 1989 r. jawi się jako zdarzenie, w którego sprawstwie udział ekipy ancien régime był minimalny lub żaden, bądź jako czynnik opóźniający „prawdziwy” przewrót. Oto na fotografii, w przekazie, zawierającym okoliczności przełomu w 1989 r., wśród jego autorów brakuje przedstawicieli minionego reżimu. Jak bardzo zabieg ten jest odległy od funkcjonowania „ministerstwa prawdy” w orwellowskim „1984”. Nie ulega bowiem wątpliwości, że czyni się tak na przekór faktom, w opozycji do prawdy historycznej.

\section{Suwerenności asymetria ujęć}

Paradoksem pozostaje - jakkolwiek zrozumiałym w kategoriach politycznych i symbolicznych - że zdarzenia, które zyskały status aktów założycielskich państwa polskiego w dwóch różnych epokach są traktowane asymetrycznie. Oto Dzień Niepodległości, 11 listopada nawiązuje do przekazania Józefowi Piłsudskiemu przez Radę Regencyjną władzy nad oddziałami polskimi, pozostającymi pod dowództwem niemieckim. O ile do tego zdarzenia przykładać miarę suwerenności absolutnej, nieuwzględniającej konkretnych okoliczności, akt ten wypadnie uznać za wszech miar niesuwerenny. Albowiem Rada Regencyjna była instytucją powołaną przez okupantów - Niemców, a Piłsudski uprzednio, i programowo współpracował z nimi oraz Austro-Węgrami. Internowany w Magdeburgu po kryzysie ,,przysięgowym" - bacznie obserwując potencjał sojuszników - w efekcie zawarcia ugody z Niemcami co do statusu wojsk niemieckich na terenie okupacji niemieckiej, został odprawiony specjalnym pociągiem (w składzie znajdowała się jedynie salonka) do Warszawy. Dzień Niepodległości związano z owym zdarzeniem, czyniąc zeń akt założycielski II RP. Ustawa z 23 kwietnia 1937 r. o Święcie Niepodległości, ustanawiała dzień 11 listopada uroczystym Dniem Niepodległości - w rocznicę odzyskania przez Naród Polski niepodległego bytu państwowego i jako dzień po wsze czasy zwiazany z wielkim imieniem Józefa Pitsudskiego, zwycięskiego Wodza Narodu w walkach o wolność Ojczyzny (art. 1) $)^{8}$.

Dzień 11 listopada 1918 r. uznano Dniem Niepodległości w czasie, kiedy chwiał się reżim sanacyjny, ulegał dezintegracji, a poparcie społeczne spadło. Reżim sanacyjny - bez jego twórcy - celem utrzymania legitymacji do rządzenia sięgnął po symbol, który wydawał się mieć - w świetle efektów dotychczasowych wysiłków propagandowych - znamiona integrujące. Wzmacniano legendę „Marszałka” i jego zasług w odzyskaniu przez Polskę niepodległości. Już w czasach legionowych kreowano wizerunek przywódcy kroczącego zdecydowanie do celu, wodza, który ojczyźnie ofiarowuje dobro najwyższe - życie. Po Zamachu Majowym owe przedsięwzięcia kreacyjne uległy wzmocnieniu poprzez udział instytucji państwa; rozbudowany system indoktrynacji, obejmował przedszkola, szkoły i wojsko... Jej treścią było kreowanie mitu założycielskiego RP, w którym główne miejsce zajmował kult Naczelnika, wybitnego wodza i męża stanu. W tym celu - w zależności od okoliczności - posługiwano się różnymi nazwami: Naczelnik, Marszałek, Dziadek, Ziuk... Dbano równocześnie o to, by kultu

${ }^{8}$ Dz. U. 1937, Nr 33, poz. 255. 
i legendy Piłsudskiego nie podważyły informacje i opinie, które ukazywałyby czyny osób niemniej zasłużonych dla Polski, skrzętnie też skrywano fakty mogące przynieść ujmę jego imieniu.

Wyolbrzymiając jego zasługi, pomija się splot różnorodnych czynników, przybliżających odzyskanie państwowości. Symbolicznym zwieńczeniem działań reżimu piłsudczykowskiego, którego twórca i rządca nie pełnił najwyższych stanowisk, lecz sprawował rzeczywistą władzę, była ustawa z dnia 7 kwietnia 1938 r. o ochronie imienia Józefa Pitsudskiego, Pierwszego Marszałka Polski. Jej art. 1. stanowił: Pamięć czynu i zastugi JÓZEFA PIESUDSKIEGO - Wskrzesiciela Niepodległości Ojczyzny i Wychowawcy Narodu - po wsze czasy należy do skarbnicy ducha narodowego i pozostaje pod szczególnq ochrona prawa. Zaś w artykule 2. orzekano: Kto uwłacza imieniu JÓZEFA PIESUDSKIEGO, podlega karze więzienia do lat $5^{9}$.

Sprawa ustanowienia Dnia Niepodległości i wiązania święta narodowego z wydarzeniem doprawdy mało znaczącym historycznie, wyolbrzymionym propagandowo i politycznie, przy równoczesnym lekceważeniu realnych okoliczności, stanowiących rzeczywiste przesłanki odzyskania przez Polskę niepodległości oraz zasług osób niemniej znaczących w owym dziele, każe pochylić się nad siłą legendy, kultem przywódcy oraz warunkami i sposobami ich kreacji.

Godzi się zwrócić uwagę na fakt, iż u schyłku Polskiej Rzeczypospolitej Ludowej, kiedy legitymacja reżimu socjalistycznego była kwestionowana, a przebieg obrad Okrąłego Stołu pozwalał sądzić, iż zbliża się nieuchronnie moment zasadniczej zmiany politycznej, Sejm PRL 15 lutego 1989 r. ustanowił 11 listopada Narodowym Świętem Niepodległości - dla upamiętnienia rocznicy odzyskania przez Naród Polski niepodległego bytu państwowego oraz walk pokoleń Polaków o wolność i niepodległość ${ }^{10}$. Zdaje się nie ulegać wątpliwości, iż ów akt zachował instrumentalny charakter, odzwierciedlając dążenia mieszczące się w obszarze władzy. Był elementem działań zmierzających do co najmniej zneutralizowania przeciwników reżimu w przewidywanej walce politycznej (wybory) ${ }^{11}$.

Powracając wszakże do II Rzeczpospolitej, nie zdołała ona obronić niepodległości. U źródeł klęski leżały różnorodne czynniki - militarne, geopolityczne, wykraczające poza możliwości, którymi dysponowała. Niemniej jednak, o ile kategorię suwerenności łączyć z racją stanu, godzi się nie pomijać tego, iż Polska międzywojenna to państwo skłócone z sąsiadami, kurczowo - za sprawą m.in. bohatera, uznawanego za podstawowe ogniwo jej aktu założycielskiego - trzymające się przebrzmiałych idei i granic, skłócone etnicznie, represyjne wobec mniejszości narodowych. A te czynniki znajdowały się w obszarze możliwości reżimu międzywojennego. Po wtóre, kwestią otwartą jest, co pozostało po niej realnie, stanowiąc ogniwo rzeczywistej tożsamości Polaków?

\footnotetext{
${ }^{9}$ Ustawa z dnia 7 kwietnia 1938 r. o ochronie imienia Józefa Pitsudskiego, Pierwszego Marszałka Polski, Dz. U. 1938, Nr 25, poz. 219.

${ }^{10}$ Ustawa z 15 lutego 1989 r. o ustanowieniu Narodowego Święta Niepodległości, Dz. U. 1989, Nr 6, poz. 34. 10 listopada 2005 r., w 87 rocznicę, Senat RP przyjął uchwałę w sprawie uczczenia Święta Niepodległości, stwierdzając, że „pokolenie” J. Piłsudskiego, R. Dmowskiego, I. Paderewskiego, W. Korfantego, W. Witosa $i$ setek tysięcy innych-imiennych i bezimiennych - bohaterów tamtych czasów, dobrze zastużyło się Polsce, dając wzór postępowania nastęnnym pokoleniom, jak za Ojczyznę walczyć, jak jej bronić, jak ja kochać. M.P. 2005, Nr 71, poz. 976.

${ }^{11}$ Podobne cele miała spełnić ustawa o stosunkach między państwem a kościołem katolickim uchwalona w $1989 \mathrm{r}$., która czyniła kościół najwcześniejszym beneficjentem „OS”. Zmierzała do jego pozyskania lub co najmniej zneutralizowania w rychłych wyborach parlamentarnych. Szerzej K. B. Janowski, Źródła i przebieg zmiany politycznej w Polsce. 1980-1989, Toruń 2004, s. 222.
} 
Na tym tle Manifest PKWN, akt założycielski Polski Ludowej, państwa polskiego odrodzonego po II wojnie światowej, wprawdzie zachowuje swój symboliczny charakter, wydaje się nieść zgoła odmienne przesłanie. Jego konsekwencje - mimo zakwestionowania źródła i politycznej podstawy - okazały się trwałe, nienaruszalne, wręcz stanowiąc element współczesnego porządku europejskiego. Najważniejszy wobec niego zarzut odnosi się do niesuwerenności. Jest on bardzo istotny, jednakże - odmiennie jak w przypadku Piłsudskiego, u którego podnosi się walory gry politycznej, jaką prowadził z państwami centralnymi - w analizie Manifestu PKWN przeważa brak zrozumienia dla jego przesłanek, jak i motywów, którymi kierowali się jego twórcy. Jego zaś skutki postrzegane są jedynie w perspektywie strat, lokowanych w syndromie komunistycznym (rosyjskim) oraz splocie minionych, tragicznych wydarzeń.

Tak więc pomija się warunki geopolityczne, które stały się udziałem Polski. Znalazła się ona po wojnie w sferze wpływów Związku Radzieckiego, co było wypadkową woli aliantów zachodnich, przede wszystkim jednak siły i pozycji ZSRR, w mniejszym zaś stopniu respektu dla dążeń Polaków. W rezultacie miała ograniczone pole manewru. Mogło powstać tylko takie państwo polskie. Innych możliwości nie było [...] Gdyby lewica nie zdecydowała się na wspótpracę z ZSRR, Polska straciłaby ziemie wschodnie i prawdopodobnie nie uzyskałaby rekompensaty na zachodzie ${ }^{12}$ - to konkluzja, której trafność trudno doprawdy kwestionować.

Manifest PKWN - akt polityczny, na którym ciążyła skaza zewnętrznej zależności - rzeczywiście odzwierciedlał presję Związku Radzieckiego, dążącego do zrealizowania swych imperialnych celów. Jakkolwiek błędem jest wykluczanie samoistności aspiracji komunistów polskich. Po wtóre, dążenia Polaków co do usytuowania ich państwa w Europie z owymi celami nie kolidowały, a ich realizacja - po trzecie - eliminowała czynniki generujące konflikty. PKWN stanął wobec tyleż delikatnej co drażliwej kwestii. Był nią sojusz i korzystanie ze wsparcia Związku Radzieckiego. Państwa, które realizując własne interesy, złamało umowy i obyczaje międzynarodowe, wkroczyło 17 września 1939 r. - w ślad za ustaleniami paktu Mołotow-Ribbentrop - na terytorium państwa polskiego. Tym samym utrwalało (odświeżało) w świadomości Polaków obraz zaborcy (rozbiory) i agresora (wojna polsko-bolszewicka), obciążanego odpowiedzialnością za eksterminację Polaków (Katyń, gułagi; wprawdzie wiedza o tych zdarzeniach nie była w społeczeństwie polskim powszechna). Stosując się do dyrektywy nakazującej strzec suwerenności, autorzy Manifestu winni odrzucić ewentualność współpracy. Wybrali wszakże kolaborację, narażając się na zarzut zdrady narodowej. Owe wybory, przed jakimi przychodzi stanąć politykom, Max Weber określał „etyką przekonań”, „absolutną”, religijną (dobro albo zło) bądź „etyką odpowiedzialności” (realność i zdolność ponoszenia skutków własnego działania), przekonując, że w polityce zło i dobro mają charakter względny. Każda etyka świata - sądził - musi stawić czoło faktowi, że osiaganie „,dobrych" celów jest w wielu wypadkach zwiqzane ze zgoda na użycie moralnie watpliwych lub co najmniej niebezpiecznych środków, jak również z tym, że możliwe lub też prawdopodobne sq złe skutki uboczne. I żadna etyka świata nie może przesqdzić, kiedy i w jakim zakresie etycznie dobry cel „uświęca” etycznie niebezpieczne środki i skutki uboczne ${ }^{13}$.

Autorzy Manifestu zapowiedzieli historyczny ${ }^{14}$ zwrot, którego sens polegał na tym, że konflikty ustępują przyjaźni i wspótpracy, dyktowanej przez obopólne życiowe interesy. Tak

\footnotetext{
12 A. Czubiński, Historia Polski XX wieku, Poznań 2003, s. 257.

${ }^{13}$ M. Weber, Polityka jako zawód i powołanie, przedmowa, wstęp i opracowanie Z. Krasnodębski, Kraków 1998, s. 102.

${ }^{14}$ Podstawą wszelkich w tekście przywołań: Manifest PKWN, Załącznik do Dz. U. 1944, Nr 1, http://www.trybunal.gov.pl/wszechnica/akty/manifest_pkwn.htm, data dostępu 14.11.2011.
} 
więc braterstwo broni miało się przekształcić $w$ trwały sojusz i w sqsiedzkie współdziałanie po wojnie. Zapewne nie bez związku z funkcjonowaniem koalicji antyhitlerowskiej formułowano kształt relacji z pozostałymi jej członkami, zapowiadając iż Polska jeszcze bardziej pogtębi przyjaźń i utrwali sojusz z Wielką Brytanią i Stanami Zjednoczonymi Ameryki Północnej oraz dażyć będzie do zachowania tradycyjnej przyjaźni i sojuszu z odrodzona Francja, jak również do wspótpracy z wszystkimi demokratycznymi państwami świata. Polska polityka zagraniczna będzie polityka demokratyczna i oparta na zasadach zbiorowego bezpieczeństwa.

Aliści najpoważniejsza zmiana dotyczyła stosunków z sąsiadami. Charakteryzowała się odwagą w przełamywaniu narosłych przez wieki urazów. Odzwierciedlała dążenie do dokonania zasadniczego przełomu we wzajemnych radziecko-polskich stosunkach, czego rząd londyński nie był w stanie dokonać. Ów przełom wypadnie porównywać z przyszłą architekturą Europy, kiedy dramatyczna przeszłość - o której nie zapominano - ustępowała wizji budowania wspólnoty, ufundowanej na wzajemnych korzyściach. Kwestią otwartą pozostawało w jakim stopniu na zaaprobowanie nowej wizji usytuowania Polski w Europie byli gotowi Polacy oraz politycy, którzy aspirowali do przywództwa?

Istota nowego układu miała zawierać się w zasadzie: ziemie polskie - Polsce, ziemie ukraińskie, białoruskie i litewskie - Radzieckiej Ukrainie, Białorusi i Litwie. W efekcie granica ta miała być liniq przyjaznego sqsiedztwa, a nie przegroda między nami a naszymi sqsiada$m i$. Sformułowane w Manifeście stanowisko w odniesieniu do granicy wschodniej wypadnie uznać za radykalne i przełomowe. Łamiąc dotąd ukształtowane stereotypy, rysowano równocześnie perspektywę kształtu stosunków z sąsiadami, których późniejsze zdarzenia nie podważały $^{15}$.

Tracąc ziemie na wschodzie, przed wiekami zagarnięte, na których władanie polskie było nadal kontestowane przez rdzenną ludność litewską, białoruską i ukraińską, Polska zyskała jednolitość narodową i terytorialną. Powracała na ziemie historycznie polskie, jakkolwiek wytrzebione z żywiołu polskiego, zyskując obszar gospodarczo i technicznie wykazujący wyższy poziom rozwoju cywilizacyjnego niż utracony. Ostateczne usytuowanie geopolityczne Polski w Europie stało się elementem świadomości Polaków, komponentem ich kultury politycznej - racjonalnego pogodzenia się ze wytworzonym stanem, ale też jego akceptacji, a nawet obrony status quo. Zważywszy dyskusyjność kategorii suwerenność oraz doznawane przyzwolenie społeczne suwerenność jawi się tedy jako pojęcie względne. Kwestią otwartą pozostaje, czy i w jakim stopniu władze reżimu PRL-owskiego zdołały ową suwerenność wykorzystać, mając na względzie polską rację stanu?

\section{Próba uporzadkowania kategorii i pojęć}

Państwa, których ustrój polityczny w okresie powojennym genetycznie wiązał się z porządkiem pojałtańskim, opatrywane są różnymi określeniami. Niejednokrotnie używane zamiennie, zdają się odzwierciedlać poszukiwania ładu metodologicznego. Każde z nich, z natury skrótowe, kryje właściwości, które mają w formie skondensowanej odbijać pewien model, który nierzadko - po upadku Związku Radzieckiego, osobliwie zaniku jego domina-

\footnotetext{
${ }^{15}$ Po 1989 r. we wzajemnych stosunkach Polski, Litwy, Białorusi i Ukrainy oraz Rosji nie kwestionowano granic. Spory dotyczą spraw aktualnych, bądź animozji sięgających przeszłości.
} 
cji w części Europy i świata - jest nadal obecny w literaturze naukowej, zwłaszcza w publicystyce.

Są to więc terminy: 1) kraje (państwa) Europy Środkowej i Wschodniej; 2) kraje komunistyczne (postkomunistyczne); 3) kraje totalitarne (posttotalitarne), czy wreszcie 4) kraje realnego socjalizmu. Ten pierwszy ma znamiona geopolityczne. Zwykle używany w określonym kontekście, sugeruje, iż niósł właśnie takie a nie inne treści ideowo-polityczne, po wtóre odnoszony jest wyłącznie do krajów, które tymi a nie innymi cechami się charakteryzowały. Aliści kraje o odpowiednich cechach ustrojowo-politycznych występowały także poza kontynentem europejskimi. W sensie aksjologicznym owe określenie charakteryzuje względna neutralność.

Implikuje on wszakże osobliwe relacje ze Związkiem Radzieckim, będącym punktem odniesienia o znamionach doktrynalno-politycznych, każąc pamiętać o jego imperialnej dominacji. Ten fakt skłania część badaczy do posługiwania się przymiotnikiem „sowiecki” (,postsowiecki”), niepomni tego, iż tłumaczy się on w języku polskim na ,radziecki”. Z racji polskich doświadczeń jest on wykorzystywany z zamiarem wywołania negatywnych skojarzenia oraz afektywnego nastawienia.

$\mathrm{Na}$ linii continuum - odchodzenia od neutralności - plasuje się określenie kraje (państwa) „komunistyczne” („,post...”), którym obejmuje się te, w których niepodzielnie rządziły partie komunistyczne, lokując je ponadto w przestrzeni „totalitarnej” (,post...”). Stanowi to próbę ogarnięcia praktyki politycznej tej grupy państw poprzez zastosowanie interpretacji doktrynalnej, jakkolwiek wykazującej znaczny stopień niewiedzy co do treści konkretnych doktryn oraz ich użyteczności w objaśnianiu rzeczywistości społecznej i politycznej. Zwykle owe terminy - nierzadko traktowane zamiennie - pozostają pod przemożną presją czynników pozanaukowych: politycznych, ideologicznych i psychologicznych. Towarzyszy im często dążenie do wytworzenia u odbiorcy negatywnych skojarzeń, łączonych z obrazem zniewolenia, przemocy oraz łamania godności i praw człowieka i obywatela.

Jednakowoż problem jest złożony, zaś występowanie zjawiska totalitaryzmu w strukturze nowożytnego państwa możliwe i prawdopodobne. Nawet $w$ najbardziej idealnym państwie rzeczpospolitej, w heglowskim państwie etycznym, tkwi potencjalna groźba immanentnego rozwinięcia ku państwu prerogatywnemu, co związane jest z dążeniem do maksymalizacji uprawnień dyskrecjonalnych ${ }^{16}$. Poddając analizie kraje (państwa), w których lokowane są przedmiotowe cechy, nie można pomijać istotnego faktu wynikającego z różnego stopnia skomunizowania i stotalitaryzowania - w sensie czasu, miejsca oraz siły reżimu - ich społeczeństw. Przede wszystkim nie jest uprawnione - co nierzadko czyniono i nadal się czy$\mathrm{ni}$ - generalne utożsamianie komunizmu z totalitaryzmem. Albowiem nie każda forma ideologiczno-polityczna i społeczna zbudowana na fundamencie koncepcji komunistycznej wyczerpywała znamiona totalitaryzmu. Wiele jej zrealizowanych - lecz niekoniecznie intencjonalnych - elementów wykazywało swoje z nim pokrewieństwo. Wyrażała ona charakterystyczne dla wszelkich utopii dążenia do uporządkowania rzeczywistości - przy równoczesnym eksponowaniu aspektów humanistycznych - wedle idealnego schematu, nie zaś - jak chcą oponenci komunizmu - immanentne „zło”, które za sprawą jego twórców miało być wpisane „od kolebki” w doktrynę socjalizmu ${ }^{17}$. Zarówno analiza komunistycznego kon-

${ }^{16}$ P. Ogrodziński, Pięć tekstów o spoleczeństwie obywatelskim, Warszawa 1991, s. 61 i 63.

${ }^{17}$ Praktyka polityczna, inspirowana przez Marksa, okazała się bowiem generować paradoksy i nieprzezwyciężalne sprzeczności - jak zauważa Adam Chmielewski, Psychopatologia życia politycznego. Podręcznik ilustrowany, Wrocław 2009, s. 87. 
ceptu, który wszak swą genezą sięga czasów starożytności, osobliwie sekty Jezusa (w j. łac. communio, -onis, to wspólność ${ }^{18}$ ), jak i jego praktycznych przejawów, nie daje podstaw do stawiania znaku równania między komunizmem ${ }^{19}$ a totalitaryzmem. Zabieg ów wypadnie uznać za przejaw ulegania lenistwu intelektualnemu, kiedy niewiedza nt. treści doktryn politycznych oraz presji poprawności politycznej wiedzie do stygmatyzacji ${ }^{20}$.

Wskazówkę otwierającą interesujące możliwości interpretacyjne zawiera pogląd Leszka Kołakowskiego, umożliwiający ponadto uwzględnianie nieodzownej stopniowalności. Dławienie swobód obywatelskich $w$ imię utrzymania i umocnienia istniejacej władzy - powiada on - nie jest jeszcze systemem totalitarnym jeśli nie towarzyszy mu inna zasada: iż wszelka działalność ludzi we wszystkich dziedzinach aktywności - ekonomicznej czy kulturalnej - musi być podporzadkowana wyłacznie celom państwa, że nie tylko zakazane sq i tepione bezwzględnie akcje skierowane przeciwko istniejacej władzy, ale także, że nie ma w ogóle $\dot{z} a d n y c h$ dziedzin życia politycznie neutralnych, $i \dot{z} e$ każdy poszczególny obywatel ma prawo do takiej tylko działalności, która jest zarazem przewidziana przez cele państwowe, że każda jednostka jest własnościa państwa i takjest przez państwo traktowana ${ }^{21}$. To ujęcie umożliwia ponadto rozróżnienie między totalitaryzmem - który jeśli pełny, udany, ma za sobą poparcie społeczeństwa (mas, ludu, narodu czy ich znaczących części) - a autorytaryzmem, reżimem niechcianym i społecznie wyobcowanym. W tej perspektywie totalitaryzm jawi się jako system bardziej prawomocny niż autorytaryzm...

Jak na tym tle lokuje się pojęcie „realny socjalizm”? Jak i poprzednie nieostre, swoim rodowodem sięga języka polityki, odzwierciedlając zespół czynników, które można odnaleźć w państwach, w których życie społeczeństwa w jego różnych wymiarach było określane doktryną oraz programem przeobrażeń socjalistycznych. Owo pojęcie wydaje się jednak bardziej neutralne ideologicznie i politycznie, niż poprzednie, a jednocześnie pojemniejsze. Jego walorem jest ujmowanie socjalizmu jako kategorii ontologicznej, jako bytu obiektywnego (w opozycji do bytu idealnego), któremu przypisuje się niepodważalną realność, odzwierciedlającą rzeczywistość hic et nunc, a więc aktualnie taką, a nie inną. Sam termin - „realny socjalizm" - wskazuje niejako implicite na nieskuteczność działań zmierzających do urzeczywistnienia idealnych celów doktrynalnych, w tym m.in.: usunięcie wszelkich dolegliwości trapiących dotąd ludzkość; powszechne szczęście i pomyślność. Godzi się tedy „pochylić” nad poglądem, wedle którego Próby modelowania życia społecznego na wzór ideologicznego projektu doprowadzity do powstania tworu o statusie heglowskiego pozoru. Sa to bowiem

\footnotetext{
${ }^{18}$ Naphta, ,jezuita w stanie spoczynku", wiodąc spór o duszę bohatera powieści Tomasza Manna, orzeka: Wszystkie ekonomiczne zasady (ojców kościoła), po wiekach zapomnienia zmartwychwstaja w nowoczesnym ruchu komunistycznym. Zgodność jest tu calkowita; ten sam sens ma nawet domaganie się władzy przez międzynarodowa pracę wbrew międzynarodowemu handlarstwu i spekulacji, przez proletariat świata, który dziś idee ludzkości i Państwa Bożego przeciwstawia burżuazyjno-kapitalistycznej zgniliźnie [...] Proletariat podjąt dzieło Grzegorza (Wielkiego), ma jego entuzjazm dla spraw boskich i tak samo jak on nie będzie mógł ręki cofnać przed krwiq. T. Mann, Czarodziejska góra, Warszawa 1982, s. 74.

${ }^{19}$ Por. K. Marks, F. Engels, Manifest komunistyczny, Warszawa 1956.

${ }^{20}$ Interesująca perspektywa poznawcza rysuje się, jeśli uznać, iż Myśl lewicowa podjęła potencjał porzucony przez liberalizm i poddała go radykalizacji. Radykalizm programu lewicy polegat, po pierwsze na postulowanym, znacznym rozszerzeniu zakresu wolności i dostępu do dóbr na grupy społeczne, które przez liberałów zostały zaniedbane i/lub wykluczone. Po drugie polegal na zwiększeniu poziomu żądań emancypacyjnych [...] samo poszerzenie zakresu działań emancypacyjnych wiodto do egalitarnych postulatów redystrybucyjnych, co ówczesny establishment, podobnie jak dzisiejszy, uznawat za nieodpowiedzialny, populistyczny radykalizm. A. Chmielewski, Psychopatologia..., op. cit., s. 85.

${ }^{21}$ L. Kołakowski, Główne nurty marksizmu, „Aneks”, London 1988, s. 177.
} 
rozwiazania systemowe i instytucje, już w samym określeniu skazane na to, iż nie moga stać się tym, co o sobie zaktadaja $q^{22}$.

W rezultacie, system socjalizmu to układ - za sprawą praktyki politycznej, pozostającej pod presją czynników wewnętrznych i zewnętrznych - który odbiegał do projektu idealnego. Począwszy od konceptu. Od zarania bowiem jego urzeczywistniania był on tworem pozbawionym naturalnych elementów go porządkujących, jak i stabilizujących: gospodarka bez podmiotów i reguł ekonomicznych; one były określane przez państwo, kierowane przez partię - z nazwy bądź założenia - komunistyczną. Władza bez polityki. Albowiem odrzucano tradycyjne jej ujęcie, jako sfery działań skoncentrowanych na władzy, określanych przez uznane i akceptowane reguły ,gry”, podejmowanej przez równorzędne podmioty polityczne. Przeciwnie, polityka uprawiana na scenie publicznej została w nim [porządku socjalistycznym - KBJ] zastapiona krypto-polityka manipulacji w obrębie zbiurokratyzowanych struktur władzy ${ }^{23}$.

$\mathrm{W}$ istocie dla promotorów owego pojęcia łączących z nim pozytywne treści, jak i przeciwników widzących w nim skondensowany wyraz totalitarnego zawłaszczenia, było skrótem myślowym. Tak więc „realny” socjalizm stanowił schyłkową fazę porządku ustrojowo-politycznego, niejako „pogodzonego" z uwarunkowaniami, z których część znajdowała się poza obszarem kreacji ideologiczno-politycznej decydenta, świadomego nieskuteczności wysiłków zmierzających do urzeczywistnienia celów w pełni odzwierciedlających Karola Marksa i Fryderyka Engelsa intelektualny koncept ideowo-polityczny.

W sensie praktycznym nawiązywał on najogólniej do celów socjalnej rewolucji ogólnoświatowej w kształcie sformułowanym przez Włodzimierza Lenina, zmodyfikowanym - bez zmiany istoty - przez Józefa Stalina i kontynuowanym - z korektami - przez jego naśladowców i następców (opcja neo- czy poststalinowska). W tym też sensie wskazywanie na cechy modelowe wydaje się uzasadnione, niezależnie od cech specyficznych: narodowych, społecznych i ekonomicznych pozwalających dostrzegać różnice.

\section{Istota ancien régime. polska po 1944 r.}

W okresie powojennym w sferze stosunków społeczno-ekonomicznych i politycznych ukształtował się system określany mianem „,demokracji ludowej”. Pamiętając o wewnętrznej niespójności logicznej pojęcia wyprowadzonego z języka polityki, można je potraktować jako skrót myślowy na określenie pewnego typu stosunków społeczno-ekonomicznych. Charakteryzował się on pluralizmem w obszarze własności środków produkcji, co odzwierciedlało istnienie sektora prywatnego i spółdzielczego, przy wzmagającej się roli państwowego i wpływie państwa na dystrybucję dochodu narodowego. Ów pluralizm był wprawdzie rychło ograniczany metodami administracyjnymi, jednakże odzwierciedlał względną autonomię gospodarki od polityki oraz (także względna) naturalność reguł i mechanizmów funkcjonowania systemu społeczno-gospodarczego.

Pluralizm znajdował również odbicie w systemie politycznym. Był on zróżnicowany pod względem działających sił politycznych i sposobów wpływania przez nie na funkcjonowanie władzy państwowej oraz wielości instytucji i organizacji umożliwiających artykułowanie

\footnotetext{
22 J. Staniszkis, Ontologia socjalizmu, Warszawa 1989, s. 8. Por. także rozważania P. Ogrodziński, Pięć tekstów..., op. cit.; osobliwie tekst pt. Rzeczywistość u wrót utopii. Próba zarysowania podwójnie dualnego modelu realnego socjalizmu.

${ }^{23}$ J. Staniszkis, Ontologia..., op. cit., s. 58.
} 
interesów społecznych i politycznych. Kształt oraz mechanizmy funkcjonowania całości życia politycznego pozwalają traktować tę fazę rozwoju systemu politycznego w Polsce jako pośrednią między typem właściwym ustrojowi demokracji parlamentarnej (z naturalnymi mechanizmami kreowania i odwoływania władzy państwowej) a typem symbolizowanym przez „realny socjalizm”, z jego uniformizmem i upaństwowieniem. Niebawem wszakże nastapiło odejście od systemu „demokracji ludowej”, czego wyrazem było biurokratyczne upaństwowienie sfery gospodarczej (nacjonalizacja, „,bitwa o handel”) oraz eliminacja opozycji środkami administracyjno-represyjnymi.

Geneza tej zmiany tkwiła w zwrocie dokonanym w Polskiej Partii Robotniczej w 1948 r. w wyniku głębokiego kryzysu ideologiczno-politycznego, przynoszącego zwycięstwo formacji zorientowanej na biurokratyczną wersję socjalizmu. Zwrot ten, dla którego decydujące okazały się impulsy zewnętrzne - jeśli ujmować jego przebieg całościowo - stanowił przerwanie deklarowanej i uznawanej przez wiodące siły polityczne ciągłości rozwojowej wiodącej - poprzez formy pośrednie o charakterze rewolucyjnym i ewolucyjnym - do uspołecznienia własności i władzy. Stało się tak w rezultacie przeniesienia - nie bez rozstrzygającego udziału rodzimego odłamu ruchu komunistycznego - rozwiązań właściwych stalinowskiej wersji przeobrażeń socjalistycznych, będącej najdrastyczniejszym wariantem socjalizmu biurokratycznego. Zwrot przynoszący zmianę filozofii władzy, motywujący forsowanie odmiennego niż w przeszłości ładu społeczno-gospodarczego i politycznego nastąpił w sytuacji postępującej stabilizacji systemu ,demokracji ludowej”, po rozstrzygnięciu - jakkolwiek osiagniętym nie bez zastosowania środków represji, manipulacji i terroru - problemów władzy państwowej, kiedy wybór dalszego wariantu ustrojowego był przesądzony.

Urzeczywistniany od jesieni 1948 r. model organizowania i sprawowania władzy (mobilizacyjno-transmisyjny ${ }^{24}$ ), który znalazł odbicie i uzasadnienie na Kongresie Zjednoczeniowym (XII 1948 r.), powołującym Polską Zjednoczoną Partię Robotniczą, generalnie był nastawiony na zabezpieczanie stosunków i struktury władzy. W jego obrębie miejsce szczególne zapewniła sobie środkami pozaprawnymi PZPR, niepodzielnie kierująca procesami społeczno-gospodarczymi i politycznymi. Istota tego systemu nie uległa zmianie do wiosny 1989 r. Praktyczne urzeczywistnianie na przełomie lat 40-tych i 50-tych zbliżało go do totalitaryzmu. Natomiast od połowy lat 50-tych przyjmował on kształt autorytarny, zaś partia rządząca, PZPR - traciła na „komunistyczności”, stając się od poł. lat 70-tych organizacją władzy $i$ interesu ${ }^{25}$. W ramach tego modelu pozostałe partie polityczne i organizacje społeczne spełniały funkcje transmisyjne woli i dyrektyw PZPR, w mniejszym zaś stopniu artykułowały interesy i dążenia swych członków. Dotyczyło to także pozostałych ogniw systemu politycznego usytuowanych podrzędnie w stosunku do partii dominującej (hegemonicznej), kreującej się na wyraziciela interesu obiektywnego „ludu pracującego”. Jej uprzywilejowana pozycja zyskała odzwierciedlenie w konstytucji.

Partia wywodziła swą pozycję nie z rządów prawa - określających m.in. demokratyczne warunki obejmowania, sprawowania, kontrolowania i odwoływania władz państwowych - lecz przeciwnie z rewolucyjnego przewrotu łamiącego właściwy im porządek. Wyrazem tego był m.in. powściagliwy (bywało - niechętny) stosunek do demokratycznej procedury

\footnotetext{
${ }^{24}$ Szerzej K. B. Janowski, Demokracja socjalistyczna w koncepcjach polityczno-programowych PZPR, Warszawa 1989.

${ }^{25}$ Proces porzucania komunistycznych korzeni w ich marksowskim kształcie z niepokojem odnotowali Jacek Kuroń i Karol Modzelewski: List otwarty do partii, Instytut Literacki, Paryż 1966, wzywając do odrodzenia w duchu walki o interesy klasy robotniczej.
} 
wyłaniania i odwoływania władzy państwowej, który znajdował teoretyczno-ideologiczne uzasadnienie w poglądzie Lenina, że władza radziecka nie powstała na drodze wyborów i nie w nich tkwi jej prawomocność ${ }^{26}$.

W tym kontekście warto zweryfikować trafność terminu „zniewolenie”, którym opatruje się sposób wpływania na społeczeństwo polskie w latach 40-tych. Ówczesne władze, formułując program radykalnych przemian - konkurencyjnych wobec prób reaktywowania porządku przedwojennego - doznawały poparcia ze strony znacznej części społeczeństwa. Tenże bowiem program, zapowiadając industrializację, urbanizację, zaspokojenie podstawowych potrzeb materialno-socjalnych, awans społeczno-kulturowy odpowiadał aspiracjom i oczekiwaniom grup niewyedukowanych, niezamożnych, zamieszkujących wieś i mniejsze ośrodki miejskie oraz pozostających zawodowo poza przemysłem; takim wszak była większość społeczeństwa polskiego. Dodatkowy czynnik - to sukcesy odniesione przez Związek Radziecki (decydujący udział w zwycięstwie nad Niemcami hitlerowskimi).

Wskazując na swoistości sytuacji w Polsce, warto uwzględnić wnioski z analizy współczesnych społeczeństw i ich dziejów, która pozwala dostrzec występowanie związku między niskim poziomem zamożności, zapóźnieniem cywilizacyjnym a gotowością zaakceptowania ekstremizmów politycznych, niesprzyjających demokracji. Natomiast wyższy poziom zamożności i wykształcenia stuża demokracji, zwiększajac podatność niższych klas na krzyżujace się naciski, ograniczajace ich zaangażowanie w poszczególne ideologie, zwłaszcza ideologie ekstremistyczne ${ }^{27}$.

W kwestii legitymizmu (prawomocności) reżimu socjalistycznego użyteczne wydaje się określenie „względna legitymizacja”, która wyrażała się w udzielaniu aprobaty warunkowej, przy braku znaczącego oporu, eliminowanego środkami perswazyjnymi, w mniejszym represywnymi. Wprawdzie brak - uznawanych współcześnie za wiarygodne - czynników, na podstawie których można byłoby określić stopień aprobaty dla systemu socjalistycznego. Jednakże pośrednie elementy zdają się wskazywać na początkowo względnie wysoki stopień akceptacji oraz - dopiero z czasem - narastający sprzeciw wobec poszczególnych jego kanonów ${ }^{28}$.

Tymczasem ubóstwo (brak) mechanizmów samoregulacyjnych, a w rzeczywistości niedostatek możliwości artykulacji interesów wytwarzał doprawdy sytuację paradoksalną. Oto kolejne bunty wobec różnych fragmentów ówczesnego reżimu niejako legitymizowały władzę, albowiem grupy, które je podejmowały żądały właśnie od niej spełnienia różnorodnych oczekiwań, kierując pod jej adresem roszczenia. To ukazywało nikłe poczucie roli i sprawstwa jednostki oraz grup społecznych. Przykładem była klasa robotnicza, gloryfikowana, deklaratywnie uznawana za demiurga rewolucji socjalistycznej. Jej najbardziej zdeterminowana część w latach 1956, 1970, 1980 wzniecała bunty wobec decyzji uderzających w jej sytuację materialno-socjalną. Owe bunty - wskutek niskiego poziomu artykulacji politycznej, charakteryzującej system - przeradzały się w protesty polityczne, traktowane w fazie początkowej jako wystąpienie o znamionach antyustrojowych. Sięganie po ów drastyczny instrument nacisku wynikało z braku, bądź nieefektywności środków wpływu, pozostających w dyspozycji społeczeństwa, osobliwie klasy robotniczej.

\footnotetext{
${ }^{26}$ M. Waldenberg, Rewolucja i państwo w myśli politycznej W. I. Lenina, Warszawa 1978, s. 350. Por. także W. Gomułka, Przemówienia (październik 1956-wrzesień 1957),Warszawa 1957, s. 193.

27 S. M. Lipset, Homo politicus. Społeczne podstawy polityki, Warszawa 1995, s. 69.

${ }^{28}$ Dokumenty zjazdu „S” we wrześniu i październiku 1981 r. nie odbiegały od doktryny socjalistycznej, K. B. Janowski, Źródła i przebieg zmiany politycznej w Polsce (1980-1989), Toruń 2004, s. 57-62.
} 
Interesujące metodologicznie podejście jawi się jeśli zaakceptować pojęcie „większa” i „mniejsza demokracja”29, odnoszone do krajów zaliczanych jednak - biorąc pod uwage uznane kryteria - do kręgu demokratycznego. Państwa socjalistyczne - mimo urzeczywistnianego leninowsko-stalinowskiego wzorca władzy politycznej - nie stanowiły bliźniaczych członów rodziny antydemokratycznej. Między nimi występowały różnice. Tak więc jedne spośród nich sytuowały się dalej, inne bliżej świata demokracji, spełniając choćby częściowo jej kanony.

Można było tedy zaobserwować istnienie obszarów wolności ideologiczno-politycznej i ekonomicznej, a także możliwości jej wykorzystania, artykułowania interesów i dążeń w ramach panującego porządku ustrojowo-politycznego, ale też kontestacji wobec jego różnych instytucji, urządzeń i mechanizmów funkcjonowania, wreszcie niezanikłe elementy społeczeństwa obywatelskiego. Ponadto sam socjalizm, nawiązując do swych humanistycznych korzeni, dążąc do urzeczywistnienia sprawiedliwości i równości społecznej, poszerzając warunki awansu społeczno-cywilizacyjnego (oświata, kultura etc) rozbudzał jednocześnie nowe potrzeby i oczekiwania, które z czasem przybierały charakter podmiotowy, kreując masę destrukcyjna.

W Polsce więc z jednej strony reżim znajdował się poza kryteriami demokratyczności wywodzonymi z tradycji liberalnej. Z drugiej jednak strony wytwarzał lub „tolerował” instytucje i mechanizmy artykulacji, regulacji i stabilizacji społeczno-ekonomicznej i politycznej, które niejednokrotnie z nazwy nawiązywały do odpowiedników znanych na gruncie demokracji parlamentarnej (parlament, sejm, partie polityczne, instytucje jak RPO, TK, TS etc.). Miały one charakter osobliwy. Wprawdzie odgrywały one rolę podrzędną wobec zasad i mechanizmów stabilizujących porządek ustrojowo-polityczny. Jednakże właśnie specyfika porządku ustrojowo-politycznego, mechanizmy władzy, jej dystrybucji oraz postawy i zachowania części społeczeństwa polskiego przesądziły o ,łagodnym” przejściu od reżimu autorytarnego do demokratycznego.

Warszawa, marzec $2012 \mathrm{r}$.

\section{Summary}

\section{On the patterns of discussing the immediate and distant past. The realm of methodological reflections on history and political theory}

The author considers the manners of discussing the past that result from an analysis of recent publications, celebrations of anniversaries, or conferences, which concern the prerequisites and uniqueness of the political transformation started in 1989. They very frequently bridge the time between the interwar period and the time following the 'round table,' implying an ideological and political connection between them, while bypassing the period of the Polish People's Republic. The perception of the past in this particular manner converges with the ideological and political trends dominating in recent Polish politics. They are exemplified by the following:

\footnotetext{
${ }^{29}$ Por. S. M. Lipset, Homo politicus..., op. cit., s. 51.
} 
1. Glorification of the interwar period. This trend officially emerged in 1989 accompanying the political transformations and has since intensified and weakened alternately. On the one hand, it is a manifestation of a kind of schizophrenia, on the other, it signifies a conscious resorting to myths, as well as the manipulation of the past;

2. Disparagement of the period of the Polish People's Republic, mixing the truth with half-truths and falsehoods. This is done for the benefit of uneducated recipients, whereas among the intelligentsia stereotypes of totalitarianism, communism, and post-communism prevail;

3. Contrasting the period after 1989 with the period of the Polish People's Republic. As was the case in the ancien régime, there prevails a tendency to disrupt developmental continuity. The Polish People's Republic is a 'black hole' in Polish history. Secondly, in contrast to the historical truth, the 1989 breakthrough appears as an event in which the ancien régime had a minute or no contribution whatsoever; alternatively this is presented as a factor that delayed the 'true' overthrow. This manipulation falls inside the scope of activities of the 'Ministry of Truth' from Orwell's 1984.

General conclusions. There is a lack of reflection, which remains in contrast to the requirements of objective description and the analysis of political phenomena and processes, an insufficient knowledge of political doctrines, a cognitive laziness, conformism and Fabianism, an intellectual avoidance of more profound analysis, a succumbing to the power of 'political correctness,' and a 'herd instinct' which epitomizes approaches to discussing both the immediate and distant past referred to in the paper. 